\title{
Mortality Trends in Finland in the 1960's
}

\author{
BY KIMMO LEPPO \\ JARL LINDGREN \\ MARKETTA RITAMIES
}

Population Research Institute

During the course of the last century, Finland has witnessed a continuous decline in general mortality similar to that occurring in all economically developed countries, and resulting from a higher standard of living along with the progress made in furthering public health. Since the turn of the century, the expectation of life at birth has risen from 45.4 years to 65.6 years for males, and from 48.0 to 72.7 years for females. As is the case elsewhere, this progress in mainly attributable to the favourable development of death rates in the younger age groups, and especially in regard to infant and child mortality.

However, some distinctive or even unique features exist in the patterns and trends of mortality in Finland in comparison with other countries. First of all, infant mortality in Finland is among the lowest in the whole world, and still exhibits a steady diminution. In 1900, infant mortality was about 130 per 1000; in 1968 the figure was 14.3 . In the whole world, only Sweden and the Netherlands registered lower figures for infant mortality in the 1960's (Moriyama 1971). The second distinctive feature is that in the older age groups mortality has declined on a much smaller scale than international comparisons and the favourable development in younger age groups would lead one to expect. Adult male mortality has continued to be very high in comparison with any other country. As a consequence, Finland holds the unofficial world record for male excess mortality. It has often been felt, at least in Finland, that this excessively high male mortality is no more than an after-effect of the heavy wars that have been fought, or a transient problem that will disappear with augmented economic well-being and better health services. However, this optimism does not appear to have any ground in reality. Accordingly, the main argument of this paper, based upon recent official vital statistics, is to demonstrate that the unique patterns of Finnish mortality are not levelling off, but rather increasing.

With a view to providing a general description of the pattern and trends of Finnish mortality in the sixties, calculations have been made of death 
rates specific for age and sex for the periods $1960-62$ and $1967-68$ for the whole country, and all the provinces. From these figures, agestandardised death rates have been calculated for the two periods mentioned, for both the whole country and all the provinces. The census population of 1960 has been used as a standard population, and all the calculations have been made separately for males and females. The age-standardised death rates illustrate the overall development of mortality trends and regional differences. In conclusion, the excess male mortality has been analysed for the whole country and for all the provinces during the two periods mentioned; the results have been compared with similar previous calculations. No detailed cause-of-death analysis has been made although this would be essential for a better explanation of the facts. In this respect, reference is due to the work of A-M Bolander (1971) of Sweden, which provides an excellent summary of recent mortality by broad cause-ofdeath groups in the Nordic countries.

\section{Age-specific death rates}

Figure 1 presents male and Figure 2 female death rates for five-year age groups during the periods $1960-62$ and $1967-68$.

The different courses of the mortality trends of males and females are immediately observable. Without a single exception, a clear decline has occurred in female death rates for all age groups. The relative change was most marked in age groups $0-4$ and $30-34$, amounting to about 30 per cent and 27 per cent respectively (cf. Appendix $1 \mathrm{a}$ and $1 \mathrm{~b}$ ). The pattern of the male curves is totally different. The male death rates declined only in age groups $0-39$. The relative change is comparable to female figures only in age group $0-4$, about 32 per cent; the next largest drop is that of 16 per cent for ages $30-34$. Nonetheless, the most remarkable feature is the consistent increase in male mortality for all age groups over 40 .

The undeviating pattern of adult male mortality, and even the occurrence of a rise in some age groups has recently been noted in a number of industrialised countries (cf. Preston 1970). Nonetheless, Finnish adult male mortality has never approached the low levels prevailing in most industrialised countries. At the beginning of the sixties, the expectation of life for Finnish males at 40 was 29.6 years. This is the lowest figure of all European countries for which data are available in the United Nations Demographic Yearbook 1967. It is even lower than the figures for many developing countries. It is not an easy matter to explain such a clear deteriorating tendency in adult male death rates in a country where the gap, in comparison with that in other countries, would still 
Figure 1. Age-specific death rates for males by five year age groups in $1960-62$ and $1967-68$.

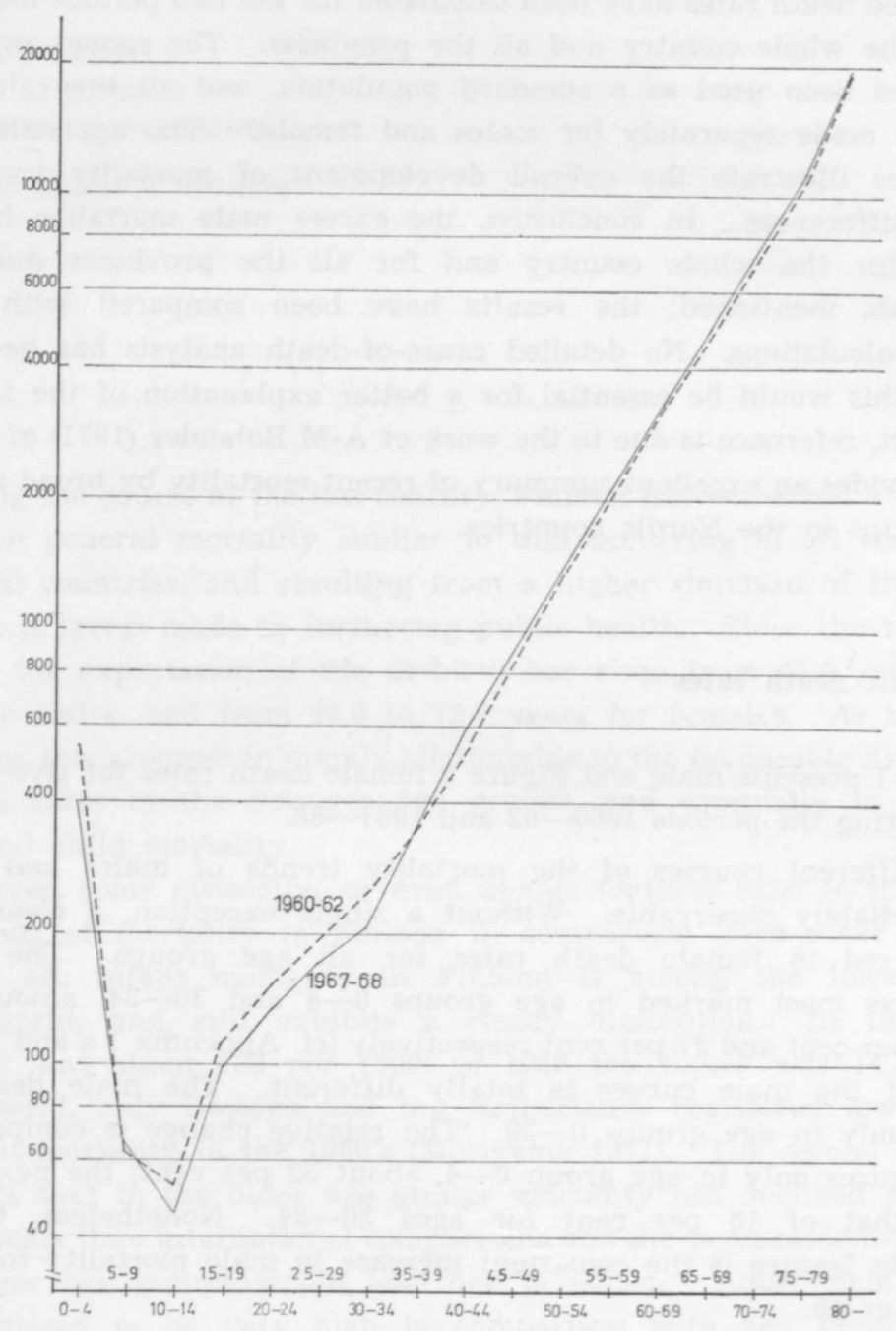

make an appreciable improvement feasible. The increase in Finnish adult male mortality during the 1960 's was at least as significant as that in other Scandinavian countries, despite it traditionally being very much higher in Finland. Of course, this implies that the gap between Scandinavia and Finland in regard to male mortality is not narrowing.

The rising trend of adult male mortality in Finland was first indicated in presentation of the new life tables for 1961-65, which showed slightly higher mortality rates for most on-year age-groups over 40 than had previously been observed. During the 1960 's this trend became even more 
Figure 2. Age-specific death rates for females by five-year age groups in $1960-62$ and $1967-68$.

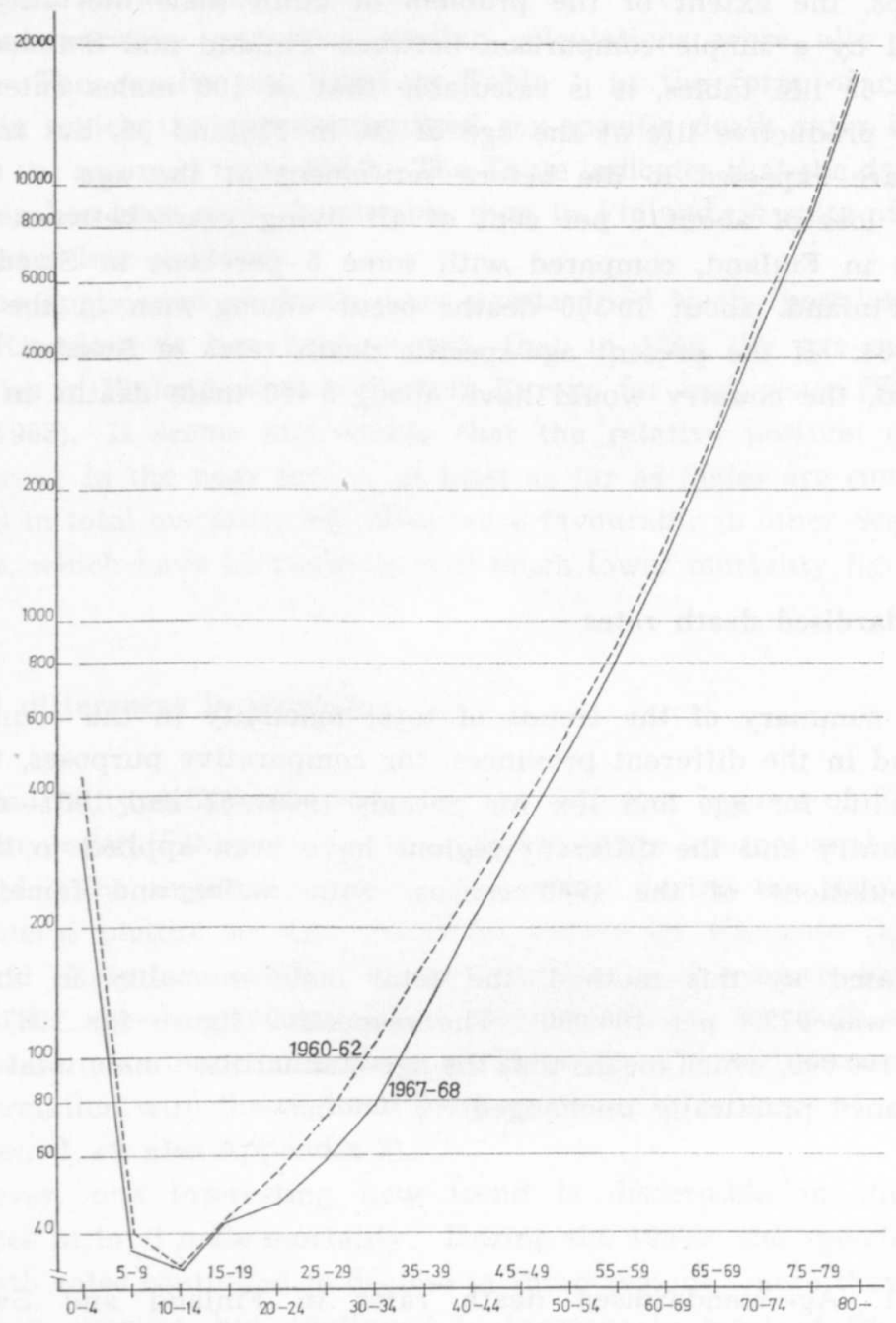

evident. From $1960-62$ to $1967-68$, the male death rates increased most clearly in age groups $40-44,45-49$, and $50-54$; the rises were $4.7,3.5$ and 4.5 per cent respectively.

One interesting point needs to be mentioned in regard to the female age-specific death rates: the "node" of the curve is gradually becoming observable in age group 15-19, where mortality had remained almost unchanged, despite the decline evident in other groups. This shift towards the male pattern probably reflects the rising number of motor vehicle accidents within the age group where a driving licence is obtained. 


\section{Some consequences of high adult male mortality}

Perhaps, the extent of the problem of adult male mortality is best illustrated by a simple comparison between Finland and Sweden. From the $1961-65$ life tables, it is calculable that of 100 males entering economically productive life at the age of 20, in Finland 36, but in Sweden only 21 are expected to die before retirement at the age of 65 . This implies a loss of about 9 per cent of all living years between the ages of $20-64$ in Finland, compared with some 5 per cent in Sweden. Each year in Finland, about 10300 deaths occur among men in the working ages $20-64$. If the present age-specific death rates of Sweden prevailed in Finland, the country would have about 5450 male deaths in this age group.

\section{Age-standardised death rates}

For a summary of the trends of total mortality in the country as a whole, and in the different provinces, for comparative purposes, the death rates specific for age and sex for periods $1960-62$ and $1967-68$ in the whole country and the different regions have been applied to the sstandard population" of the 1960 census, with males and females given separately.

Calculated by this method, the total male mortality in the period 1960 - 62 was 972.7 per 100000 . The respective figure for $1967-68$ was 976.1 per 100000 , which means that the age-standardised male total mortality has remained practically unchanged.

Table 1. Age-standardised death rates in Finland and Sweden in 1960-62 and 1967-68.

\begin{tabular}{lcccc} 
& \multicolumn{2}{c}{ Finland } & \multicolumn{2}{c}{ Sweden } \\
Per 100000 & $1960-62$ & $1967-68$ & $1960-62$ & $1967-68$ \\
& & & & \\
Males & 972.7 & 976.1 & 625.7 & 611.9 \\
Females & 851.5 & 790.1 & 664.4 & 595.6 \\
Index & & & & \\
Males & 100.0 & 100.3 & 64.3 & 62.9 \\
Females & 100.0 & 92.8 & 78.0 & 69.9
\end{tabular}

The standard population used is the Finnish census population 1960, males and females separately. Comparative index $100.0=$ Finnish death rates $60-62$ applied to standard population. 
Calculated in the same way, the total female mortality was 851.5 in $1960-62$, and 790.1 in $1967-68$, implying a 7.2 per cent reduction in agestandardised female total mortality.

For comparative purposes, similar calculations were also made for Sweden. The results are listed in Table 1 in the form of comparable indices, in which the age-standardised sex-specific death rates in Finland $1960-62$ are assumed to be 100.0. The Table indicates that the development in Sweden has been more favourable than in Finland, in spite of Sweden's already very low mortality.

By the application of death rates standardised to the population of the United Kingdom, it has been shown, that in 1965 the age-standardised death rates in Finland were highest in Europe for both sexes (The Annual Report 1968). It seems improbable that the relative position of Finland will improve in the near future, at least as far as males are concerned, as the trend in total mortality has been more favourable in other Scandinavian countries, which have by tradition had much lower mortality figures.

\section{Regional differences in mortality}

The mortality differences between the different regions of Finland are noteworthy, even if they are less in extent than the international differences mentioned. The regional mortality differences during the 1960's give the same general picture as that presented earlier by Kannisto (1947), Härö (1966) and Strömmer (1969). In the southern and western parts of the country, the age-standardised death rates are lower for both sexes than in the eastern and northern parts of Finland. These differences bear a close correlation with the regional socio-economic differences of the country (Cartogram 1, cf. also Appendix 2).

However, one interesting new trend is discernible in the regional differences in total male mortality. During the 1960's, the age-standardised male death rates continued to decline in those regions where they had been lower than average, but continued to increase in most of those regions where they had been higher than average. Most striking was the increase in North Carelia (Pohjois Karjalan lääni). Accordingly, the male mortality differential between regions widened further. However, in respect of females, the age-standardised death rate declined in almost every region. The reduction in female rates was quite appreciable both in the northernmost and the southernmost parts of the country, and during both periods the range of regional differences was of the same order.

Some form of cumulative process seems to have taken place in the male mortality differences between regions. In part, this could possibly be accounted for by the migration from the underdeveloped to more developed provinces. Nevertheless, the fact remains that female mortality 


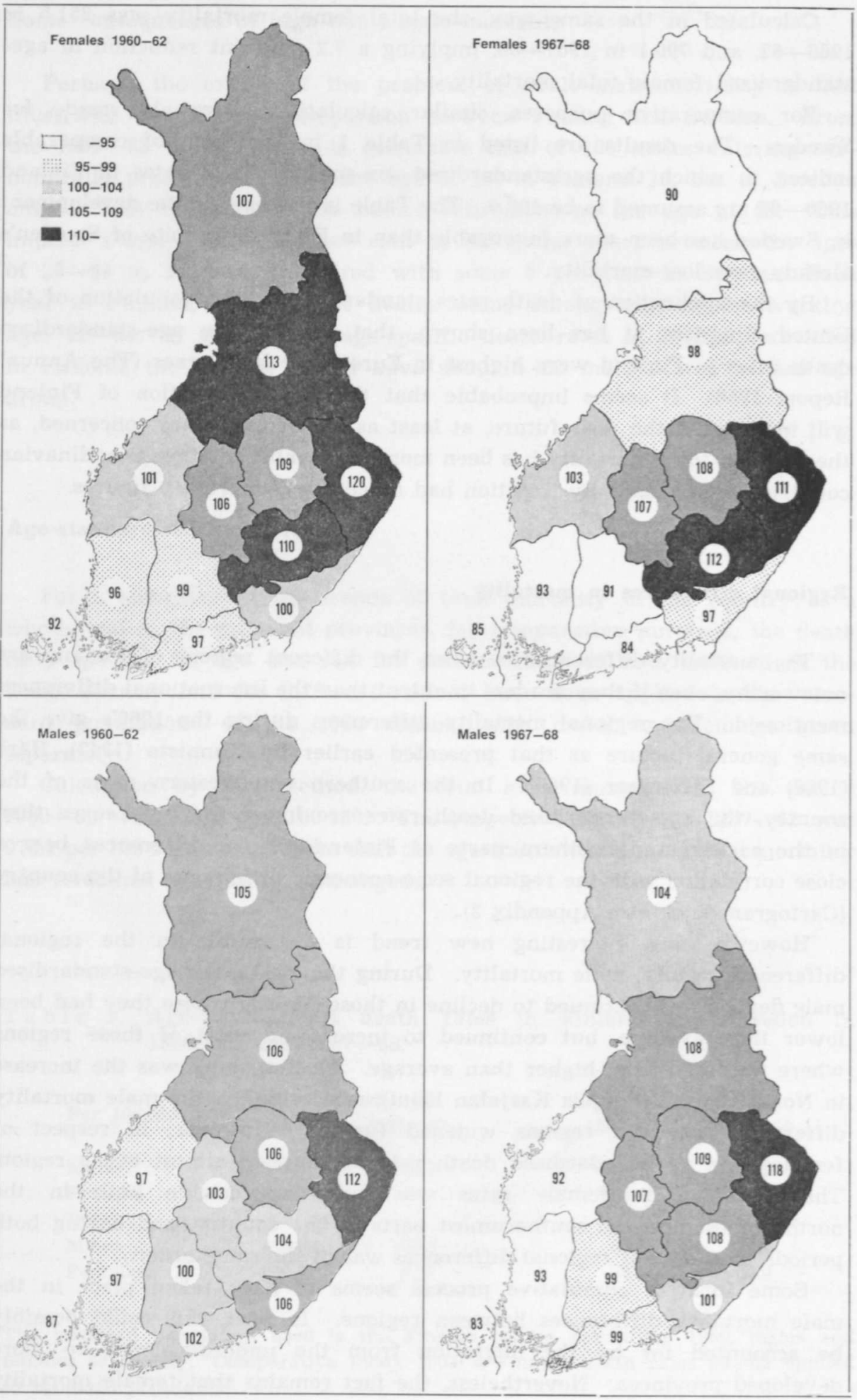


Cartogram 1. Age standardised death rates for females and males in $1960-62$ and $1967-68$, by administrative province.

$\leftarrow$

Administrative provinces $\rightarrow$

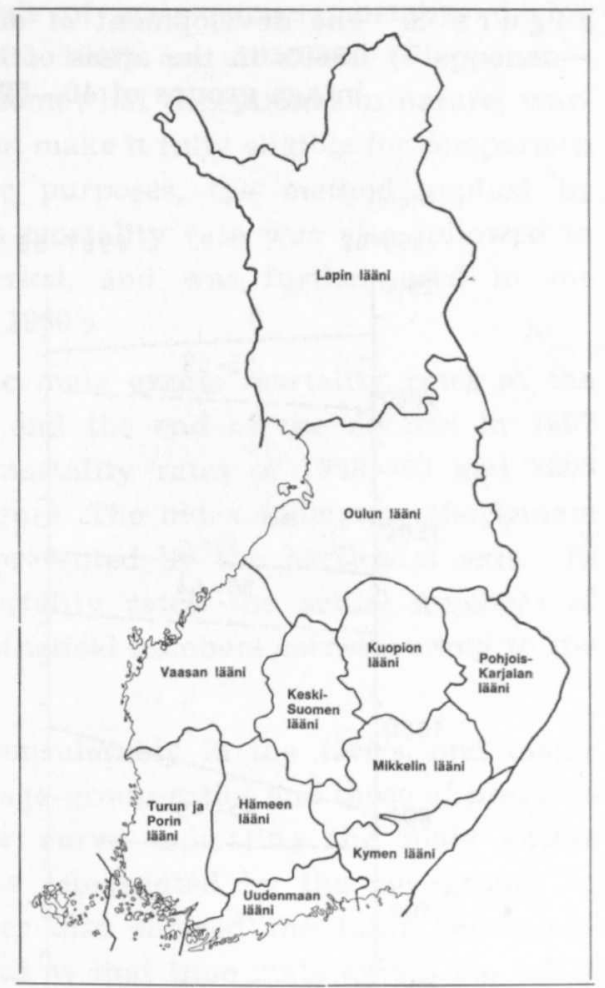

differences have not followed the same course, so that selective migration is at best no more than a partial explanation. Moreover, the fact that the increase in mortality was most marked in age groups with only slight migration argues against this hypothesis.

As was mentioned above, the increase in the male death rate was most accentuated in the ages 40 to 54 during the period under review. For examination of whether any divergence was apparent between different parts of the country, a comparison was made of the development of the death rates of the age-groups in late middle-age in respect of the areas of lowest and highest mortality in Finland. Figure 3 indicates that the female death rates in the areas with lowest mortality - represented by the southern and western parts of the country - diminished at least by the same extent as they did in those of highest mortality, i.e. northern and eastern Finland. Contrary to this, the male rates exhibited a tendency to increase slightly in three of the age groups in the southern and western parts. In the regions of high mortality, the increase was most appreciable in the age group 45-49. The youngest and eldest age groups even showed a decline during the 1960 's. Only a detailed analysis could provide an explanation for the irregularity of the development in different age groups. 
Figure 3. The development of death rate per 100000 during 1960 's in the areas of highest and lowest mortality, in age groups of $40-59$ years.

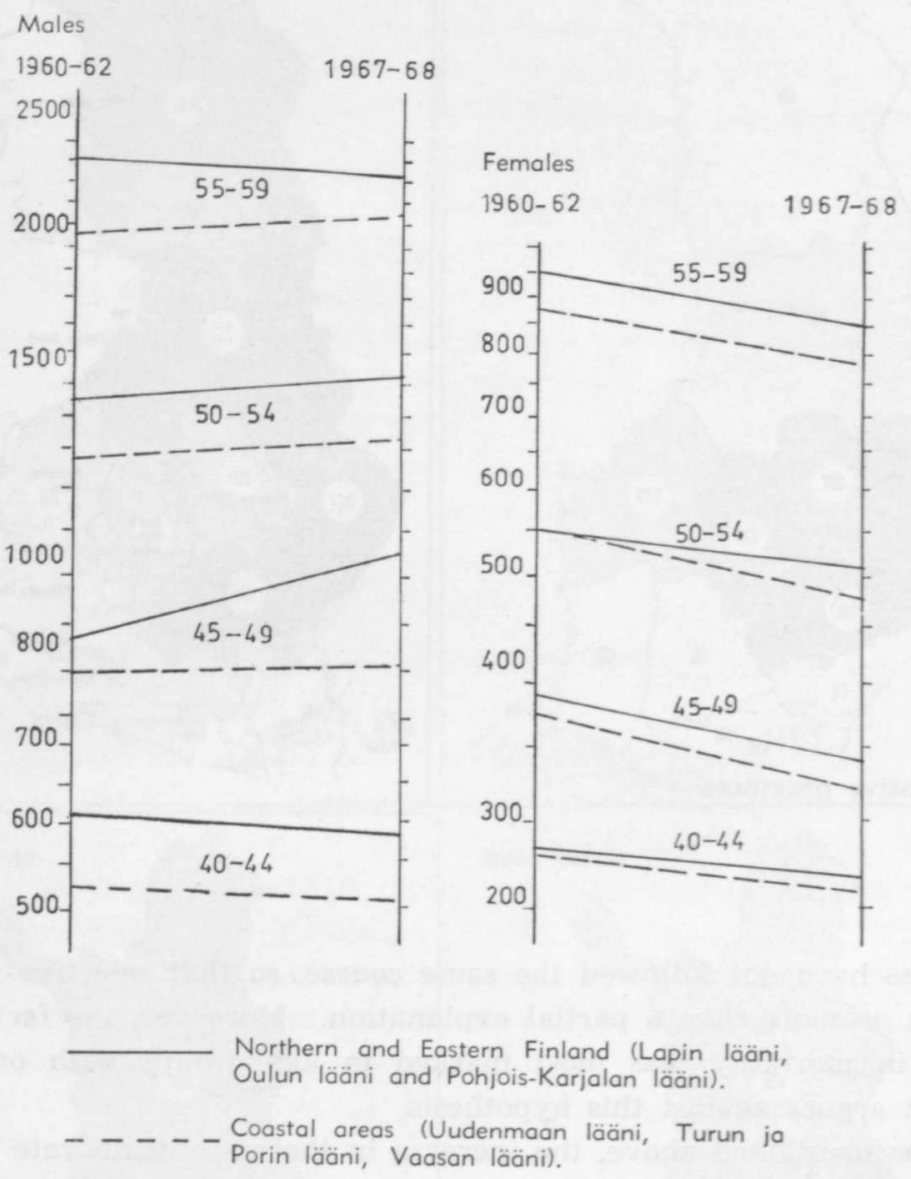

\section{Male excess mortality}

The higher mortality of men than that of women - male excess mortality - is a phenomenon apparent almost everywhere. In Finland, male excess mortality has reached considerable proportions and exceeds that in most developed countries. This is evident in all age groups, although within the last few years it has increased most appreciably among the population of $15-64$ years of age. 
In Finland, studies have been made of male excess mortality during two earlier periods, 1938-43 (Kannisto 1947) and 1956-60 (PiepponenRitamies 1966). The first period was somewhat exceptional in nature, wartime, and the picture it provides does not make it fully eligible for comparison with later periods. For comparative purposes, the method applied by Kannisto for calculation of the excess mortality rate was also followed in calculations relating to the later period, and was further used in the following estimates concerned with the 1960's.

Figure 4 illustrates the age-specific male excess mortality rates at the beginning of the 1960 's, in $1960-62$, and the end of the decade, in 1967 -69. Curves indicating the excess mortality rates of $1938-43$ and 1956 -60 have been incorporated in the figure. The index indicating the female mortality rate is 100 , and is thus represented by the horizontal axis. In the establishment of male excess mortality rates, the actual numbers of male deaths were compared with hypothetical numbers corresponding to the respective female deaths. ${ }^{1}$

Male excess mortality rates rose considerably in the 1960's, and major changes became apparent between the age-group-ratios and those of previous decades. In the years $1956-60$, the curve indicating the male excess mortality rate had two distinct peaks represented by the age groups of 15-34 and 45-64. Kannisto's figures also showed the faint beginnings of two peaks in the years $1938-43$, but at that time male excess mortality appeared mainly in the older age groups, with the peak occurring in respect of 50-54-year-olds. In the 1960's, the weight increasingly shifted towards younger age groups. In the years $1960-62$, the excess mortality rate of the 15-29 age group was already much higher than that of older age groups, although two peaks were still clearly discernible in the curve. By the end of the decade, the excess mortality rate of young men had risen even more, and particularly so in regard to the 35-44 age group. This resulted in smoothing out of the excess mortality rate curve, involving more or less all age groups of $15-64$ years of age. In reality, the male mortality rate declined within the young age groups in the 1960's. The increase in the excess mortality rate was attributable to the simultaneous distinct decline in the female mortality rate.

To date, but little study has been concerned with the reasons for male excess mortality in Finland. Kannisto, while examining the excess mortality rates of 1938-43, established that some causes of death had an especially high male preponderance rate. In particular, suicide, accidents, stomach diseases and pneumonia were causes of death clearly typical of males. However, in the years 1956 - 60, causes of death more typical of males were lung cancer, suicide, bronchial tuberculosis and accidents. It must be

1 For an explanation of the method used refer to the footnote in Figure 4. 
Figure 4. Age-specific male excess mortality rates at the beginning of the 1960's, 1960-62 and in 1967-69. Age specific female mortality $=100$.

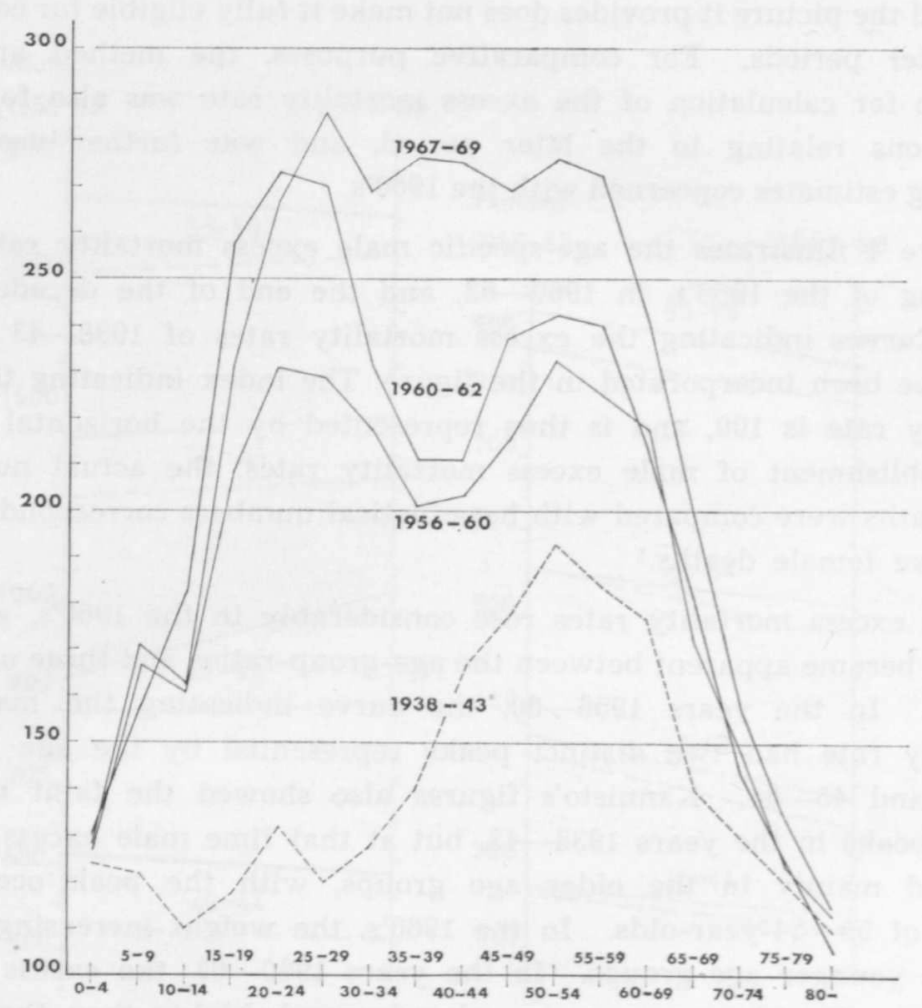

The index representing the male excess mortality is $\frac{d_{x}^{m}}{d_{x}^{w}} \cdot \frac{L_{x}^{w}}{L_{x}^{m}}$ where $\mathrm{d}_{\mathrm{x}}^{\mathrm{m}}=$ male deaths of age group $\mathrm{x}$,

$\mathrm{L}_{\mathrm{x}}^{\mathrm{w}}=$ number of women of age group $\mathrm{x}$,

$\mathrm{d}_{\mathrm{x}}^{\mathrm{w}}=$ female deaths of age group $\mathrm{x}$ and

$\mathrm{L}_{\mathrm{x}}^{\mathrm{m}}=$ number of men of age group $\mathrm{x}$.

borne in mind that a high male preponderance rate for some cause of death does not necessarily always mean that large numbers of men succumbed to it. The magnitude of the excess mortality rate is solely dependent upon the ratio between male and female deaths.

The increase in the male excess mortality rate in the 1960's is partially explicable by the age-specific mortality rate figures mentioned earlier. Female mortality rates declined in all age groups, and counsequently the 
male excess mortality rate seems to have risen, although, in reality, the male mortality rate, for example that among 0 - 39-year-olds, declined in the 1960's.

Since the causes of male excess mortality have not been investigated in Finland, it is necessary to refer to Bolander's (1971) research work into the cause of death in the Nordic countries. One of the factors that lead to the high excess mortality rates of young men is probably the rise in accidental deaths. In 1966-68, Finnish men were found to head the list as regards death by accident, poisoning and violence. In comparison with other Scandinavian countries, the difference became especially evident in age groups over 15-19 years. Road deaths were also highest among Finnish men aged 15 years and over. This also applied to suicides: Finnish men headed the list in all age groups.

\section{Regional differences in excess male mortality}

The age-specific male excess mortality rates presented were calculated according to the average for the entire country. However, it is also important to take regional differences into consideration, since the industrial and social structure of the different regions of the country may vary quite considerably, and thus affect the excess mortality rate.

The male excess mortality rate is presented in Figure 5 by provinces at the beginning and the end of the decade in the form of a bar chart. The index-figures were found by comparison of the ratio of male deaths in the administrative provinces to the male population of the whole country, with the corresponding female figures (cf. footnote in Figure 5). This method of calculation corresponds to that applied earlier in the Kannisto and Piepponen-Ritamies reports.

In the early 1960's, Uudenmaan lääni was the only province in Finland with no male excess mortality. In the coastal area in general, in Vaasan lääni, in Turun and Porin lääni, as well as in Uudenmaan lääni male excess mortality was lower than that in the interior. The male excess mortality rate was highest in the northern and eastern parts of the country, in Lapin lääni, Oulun lääni and Pohjois-Karjalan lääni.

In the 1960's the male excess mortality rate increased throughout the country with the exception of Kymin lääni. In 1967-68, male excess mortality was already apparent in all the provinces, although the male preponderance rate of mortality in the coastal areas continued to be less than that elsewhere in the country. From the early 1960's until $1967-68$, the male excess mortality rate grew in the different provinces as indicated in Figure 5. 
The percentage of growth of excess mortality was highest in the southernmost and northernmost regions of the country.

On examination of the excess mortality of males in 1956-30, Kannisto established that the excess mortality was highest in the coastal areas, but Piepponen and Ritamies produced a contradictory result, that the male preponderance was lowest in the coastal areas. The reason for this change was sought in migration, which reached considerable proportions in the 1950's. However, the male excess mortality is inexplicable by migration; at most, it can be regarded as a partial reason.

It was shown earlier that the age-standardised mortality rates had declined in those areas where the mortality rate was already low, and had grown in high mortality areas. Correspondingly, female figures declined in the whole country, although this fall was most noticeable in the southernmost and northernmost areas of Finland. The male excess mortality then rose throughout the country during the 1960's. The decline in the female mortality rate, particularly in the southern and northern areas of the country, provides an explanation of why the percentage of growth in the male excess mortality rate was most marked in Northern Finland and Uusimaan lääni.

Figure 5. Male excess mortality index in 1960-62 and in 1967-68, by administrative provinces.

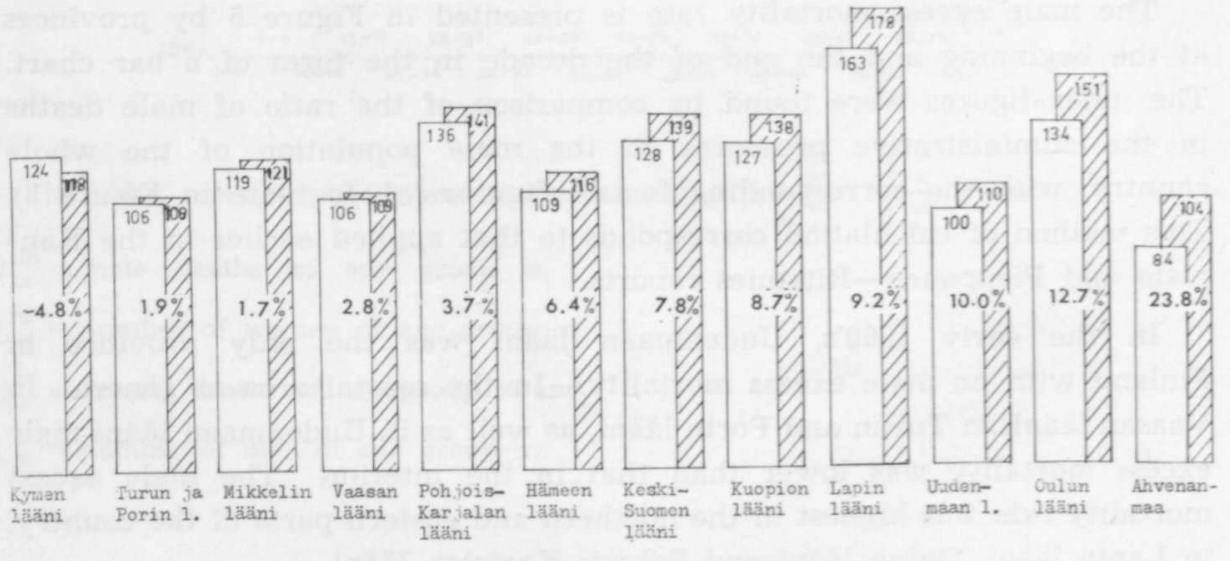

The index representing the excess mortality is $\frac{d_{p}^{m}}{d_{p}^{w}} \cdot \frac{L w}{L m} \cdot 100$, where $\mathrm{d}_{\mathrm{p}}^{\mathrm{m}}=$ total number of deaths among men of different provinces,

$\mathrm{d}_{\mathrm{p}}^{\mathrm{w}}=$ total number of deaths among women of different provinces,

$\mathrm{L}^{\mathrm{w}}=$ number of women in the whole country and

$\mathrm{L}^{\mathrm{m}}=$ number of men in the whole country. 


\section{Some comments}

The real reasons that lie behind the unusual patterns and trends of Finnish mortality are to a great extent a matter for conjecture. In fact, very little demographic research into mortality has been undertaken in Finland. As a consequence, no more than some speculations and suggestions for further research can be offered.

The unusually high male death rates are not concentrated within any category of single disease, although cardiovascular diseases bear the responsibility for a major proportion of deaths. In respect of almost all causes of death, Finnish men die at a lower age than other Scandinavians (Bolander 1971). It is probable than this multi-causal over-mortality has itself multifactorial etiology. The facts that child and maternal mortality figures are quite favourable, and that children and mothers are the only groups offered effective preventive medical care, suggest that one of the reasons for high adult male mortality could be deficiencies in the organisation of health services for adults, and in particular males. Preliminary results from a study of medical care utilisation in seven countries (WHO/ICS-MCU) seem to show that Finns make very little use of the health services as compared with other nations. The lack of services, along with the expenditure involved, is the most plausible reason for the negative attitude towards medical care which, it is frequently alleged, is adopted by Finnish men.

It is probable that the regional differences in mortality are largely owing to general socio-economic differences, including divergences in occupational structure, the supply of and the use made of health services, and the selective migration from under-developed to developed regions.

Moreover, genetic factors can not be excluded as a partial explanation of some distinct characteristics of Finnish mortality. For centuries, the Finnish population has formed a genetic isolate; although we know very little about the inheritance of the diseases that cause most morbity and mortality, it is possible that genetic isolation could be one reason for the »excess prevalence» and death rates attributable to these diseases (Nevanlinna 1968).

A great need exists for more research into morbidity and mortality in Finland. Basic vital statistics are unusually good and reliable, but for the most part they have not been the subject of analysis. Even a detailed "cause-of-death" analysis has not been made, not to mention the determination of socio-economic or occupational differences in mortality, or a joint effort undertaken by physicians, demographers and sociologists to shed more light upon the reasons for the special features of Finnish mortality. 
க

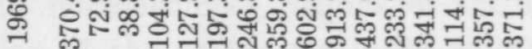
$\rightarrow \mathrm{N}$ 以ू

$\begin{array}{ll}\infty & \infty \\ \text { कू } & 5 \\ -1 & 5\end{array}$

\%

ङ नं

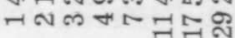

กุ.

$\stackrel{\leftrightarrow}{\circ}$

ᄋ̊ำ

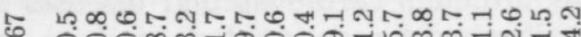

क Sूर

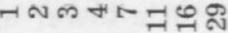

ஜื

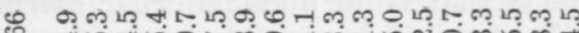

कू गें ーN m

$18 \infty$ ก

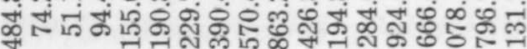
-NलH

ำ

क्न ทヘ

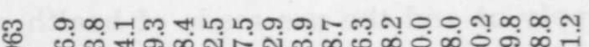

\&

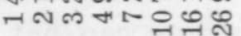

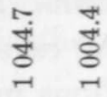

ข

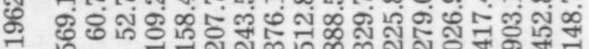
-N

ஜु

ปุ$$
\text { कै }
$$

ఫु

-

\&

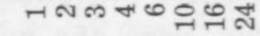

-

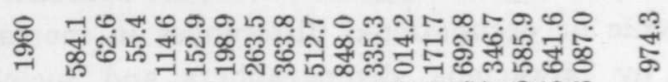
- 1 m<smiles>C=[Te]</smiles> 


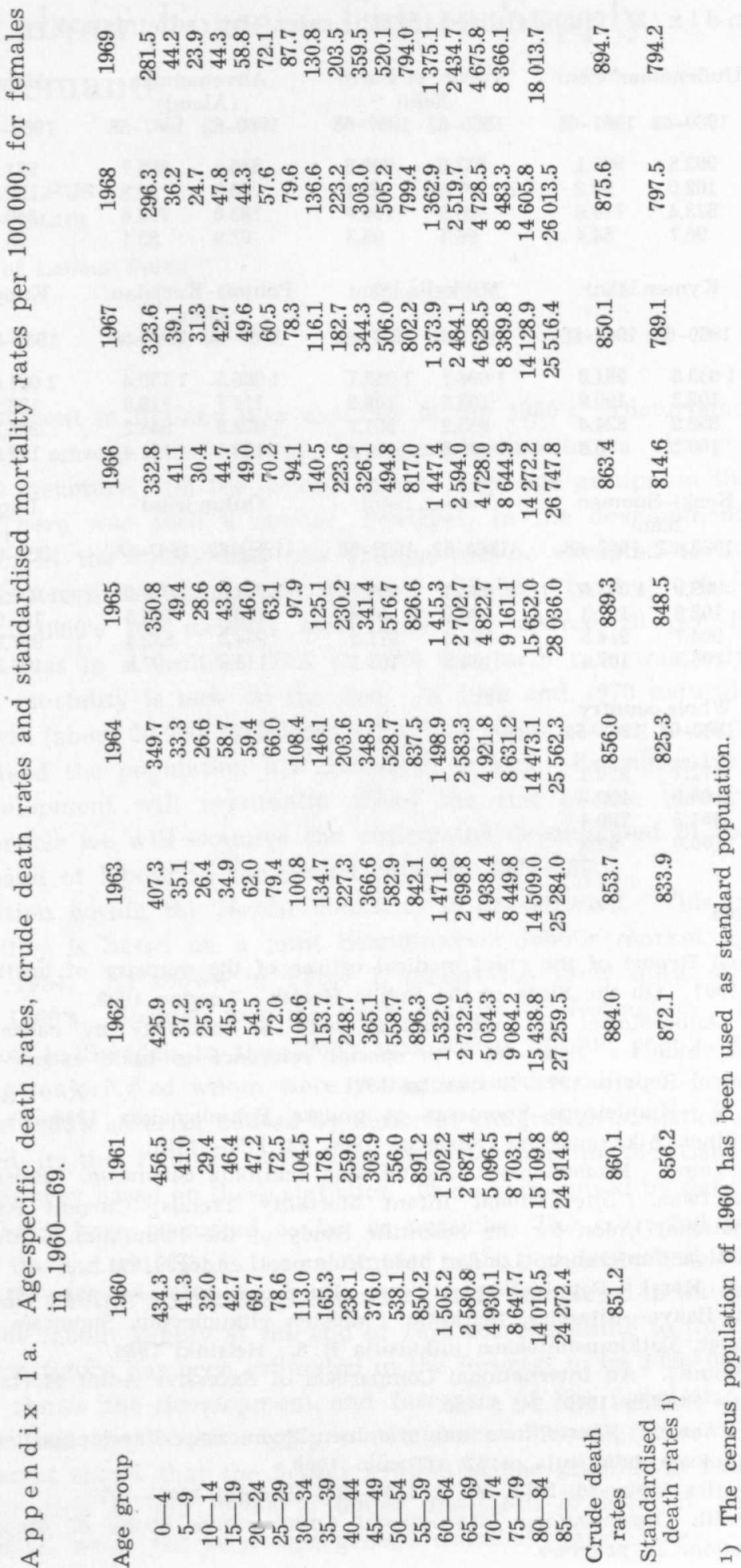


Appendix 2. Standardised death rates, by administrative provinces.

\begin{tabular}{|c|c|c|c|c|c|c|c|c|}
\hline \multirow[b]{2}{*}{ Sex } & \multicolumn{2}{|c|}{ Uudenmaan lääni } & \multicolumn{2}{|c|}{$\begin{array}{c}\text { Turun ja Porin } \\
\text { lääni }\end{array}$} & \multicolumn{2}{|c|}{$\begin{array}{l}\text { Ahvenanmaa } \\
\text { (Aland) }\end{array}$} & \multicolumn{2}{|c|}{ Hämeen lääni } \\
\hline & $1960-62$ & $1967-68$ & $1960-62$ & $1967-68$ & $1960-62$ & $1967-68$ & $1960-62$ & $1967-68$ \\
\hline $\begin{array}{l}\text { Males } \\
\text { Index }\end{array}$ & $\begin{array}{l}992.8 \\
102.0\end{array}$ & $\begin{array}{r}965.1 \\
99.2\end{array}$ & $\begin{array}{r}933.6 \\
970\end{array}$ & 908.6 & 845.3 & 805.7 & 971.3 & 960.2 \\
\hline $\begin{array}{l}\text { Index } \\
\text { Females }\end{array}$ & $\begin{array}{l}102.0 \\
823.4\end{array}$ & 718.9 & & & 86.9 & 82.8 & 99.9 & 98.7 \\
\hline Index & $\begin{array}{r}80.4 \\
96.7\end{array}$ & 84.4 & $\begin{array}{r}820.9 \\
96.4\end{array}$ & $\begin{array}{r}794.0 \\
93.3\end{array}$ & $\begin{array}{r}783.0 \\
92.0\end{array}$ & 724.6 & 840.6 & $\begin{array}{r}773.3 \\
90.8\end{array}$ \\
\hline & \multicolumn{2}{|c|}{ Kymen lääni } & \multicolumn{2}{|c|}{ Mikkelin lääni } & \multicolumn{2}{|c|}{$\begin{array}{c}\text { Pohjois-Karjalan } \\
\text { lääni }\end{array}$} & \multicolumn{2}{|c|}{ Kuopion lääni } \\
\hline Sex & $1960-62$ & $1967-68$ & $1960-62$ & $1967-68$ & $1960-62$ & $1967-68$ & $1960-62$ & $1967-68$ \\
\hline Males & 1033.6 & 981.6 & 1006.7 & 1052.7 & 1086.5 & 1150.4 & 1031.6 & 1063.5 \\
\hline Index & 106.3 & 100.9 & 103.5 & 108.2 & 111.7 & 118.3 & 106.1 & 109.3 \\
\hline Females & 852.9 & 824.4 & 935.2 & 951.7 & 1022.9 & 948.2 & 926.2 & 875.7 \\
\hline Index & 100.2 & 96.8 & 109.8 & 111.8 & 120.1 & 111.4 & 108.8 & 108.2 \\
\hline & \multicolumn{2}{|c|}{$\begin{array}{l}\text { Keski-Suomen } \\
\text { lääni }\end{array}$} & \multicolumn{2}{|c|}{ Vaasan lääni } & \multicolumn{2}{|c|}{ Oulun lääni } & \multicolumn{2}{|c|}{ Lapin lääni } \\
\hline Sex & $1960-62$ & $1957-68$ & $1960-62$ & $1967-68$ & $1960-62$ & $1967-68$ & $1960-62$ & $1967-68$ \\
\hline $\begin{array}{l}\text { Males } \\
\text { Index }\end{array}$ & $\begin{array}{l}999.9 \\
102.8\end{array}$ & $\begin{array}{r}1043.6 \\
107.3\end{array}$ & $\begin{array}{r}942.1 \\
96.9\end{array}$ & 899.1 & 1031.8 & 1053.2 & 1021.4 & 1011.7 \\
\hline Females & $\begin{array}{l}102.8 \\
904.7\end{array}$ & 914.5 & $\begin{array}{r}90.9 \\
856.0\end{array}$ & 92.4 & 106.0 & 108.3 & 105.0 & 104.0 \\
\hline Index & $\begin{array}{l}904.7 \\
106.3\end{array}$ & 107.4 & $\begin{array}{l}856.0 \\
100.5\end{array}$ & 877.5 & 964.3 & 832.4 & 907.2 & 764.7 \\
\hline & \multirow{2}{*}{\multicolumn{8}{|c|}{$\begin{array}{l}\text { Whole country } \\
1960-62 \quad 1967-68\end{array}$}} \\
\hline Sex & & & & & & & & \\
\hline Males & 972.7 & 976.1 & & & & & & \\
\hline Index & 100.0 & 100.3 & & & & & & \\
\hline Females & 851.5 & 790.1 & & & & & & \\
\hline Index & 100.0 & 92.8 & & & & & & \\
\hline
\end{tabular}

\section{References}

The Annual Report of the chief medical officer of the ministry of health for the year 1967. On the State of the Public Health. London 1968.

Bolander, Anne-Marie. A comparative study of mortality by cause in four Nordic countries, 1966-68, with special reference to male excess mortality. Statistical Reports 1971. Stockholm 1971.

Härö, A. S. Kuolleisuus Suomessa ja muissa Pohjoismaissa 1948-64. Lääketieteellinen Aikakauskirja Duodecim 1966, 82, 1136-1151.

Kannisto, Väinö. Kuolemansyyt väestöllisinä tekijöinä Suomessa. Helsinki 1947.

Moriyama, Iwao. International Infant Mortality Trends: Current Assessment. International Union for the Scientific Study of the Population. International Population Conference. London 1969, Volume II. Liege 1971.

Nevanlinna, Harri. Populaatiogenetiikka. Duodecim 1968: 84, 464-481.

Piepponen, Paavo-Ritamies, Marketta. Miesten ylikuolevuus Suomessa. Väestöpoliittisen Tutkimuslaitoksen julkaisuja B: 8. Helsinki 1966.

Preston, Samuel. An International Comparison of Excessive Adult Mortality. Population Studies 1970: 24, 5-20.

Strömmer, Aarno. Väestöllinen muuntuminen Suomessa. Väestöpoliittisen Tutkimuslaitoksen julkaisuja A: 13 . Tornio 1969.

Vital Statistics 1960-68, SVT VI A: $119-130$. Helsinki 1962-1970.

World Health Organization. International Collaborative Study of Medical Care Utilization. In progress. 